\title{
JOBS AND RENEWABLE ENERGY PROJECT
}

\section{Final Technical Report}

\author{
Submitted by \\ George Sterzinger \\ December 2006
}

\section{DOE Award Number DE-FC36-04G014213}

\author{
Renewable Energy Policy Project \\ (REPP) \\ 1612 K Street, Suite 202 \\ Washington, DC 20006
}

George Sterzinger, Principal Investigator

Renewable Energy Policy Project (REPP)

1612 K. Street, Suite 202

Washington, DC 20006

(202) 293-2898

Email: gsterzinger@repp.org 


\section{DISCLAIMER}

This report was prepared as an account of work sponsored by an agency of the U.S. government. Neither the United States Government nor any agency thereof, nor any of their employees, makes any warranty, express or implied, or assumes any legal liability or responsibility for the accuracy, completeness, or usefulness of any information, apparatus, product, or process disclosed, or represents that its use would not infringe privately owned rights. Reference herein to any specific commercial product, process, or service by trade name, trademark, manufacturer, or otherwise does not necessarily constitute or imply its endorsement, recommendation, or favoring by the U.S. government or any agency thereof. The views and opinions of authors expressed herein do not necessarily state or reflect those of the U.S. government or any agency thereof. 


\section{Table of Contents}

Executive Summary

Task 1

Task 2

Task 3

Task 4

Task 5

Task 6

Task 7

Conclusion
Page 1

Page 2

Pages 3-4

Pages 5-9

Page 10

Pages 10-13

Page 13

Page 13-14

Page 15 


\section{Executive Summary}

The Jobs and Renewable Energy Project grant been in place for several years and has accomplished all the objectives that were originally set forth in the proposal. REPP and its partner, the Nevada State AFL-CIO, have been able to successfully develop and implement enhancements to the REPP Jobs Calculator model, add a jobs locator data base to that work, and establish training programs for PV installers in the State of Nevada. In addition REPP has worked directly with groups in Nevada to identify and capture the economic benefits related to the Nevada Renewable Portfolio Standard.

The Jobs and Renewable Energy Project had seven specific tasks:

1. Form Advisory Council from Renewable Energy Trade Associations

2. Develop Labor Calculator

3. Develop and Implement Jobs Locator

4. Outreach

5. Form Nevada Advisory Council to Review Opportunities and Determine Appropriate Response to Renewable Opportunities

6. Participate in the Governor's Task Force on Renewable Energy

7. Progress Conference

As a result of this project, labor, federal and state policy makers, and clean energy advocates will better understand the economic impact of renewable energy installation on a geographic level. 


\section{Project Background}

Early in 2002, REPP developed the Jobs Calculator, a tool that calculates the number of direct jobs resulting from renewable energy development under RPS (Renewable Portfolio Standard) legislation or other programs to accelerate renewable energy development. The calculator is based on a survey of current industry practices to assess the number and type of jobs that will result from the enactment of a RPS.

This project built upon and significantly enhanced the initial Jobs Calculator model by (1) expanding the survey to include other renewable technologies (the original model was limited to wind, solar PV and biomass co-firing technologies); (2) more precisely calculating the economic development benefits related to renewable energy development; (3) completing and regularly updating the survey of the commercially active renewable energy firms to determine kinds and number of jobs directly created; and (4) developing and implementing a technology to locate where the economic activity related to each type of renewable technology is likely to occur.

REPP worked directly with groups in the State of Nevada to interpret the results and develop policies to capture as much of the economic benefits as possible for the state through technology selection, training program options, and outreach to manufacturing groups.

\section{Task 1: Form Advisory Council from Renewable Energy Trade Associations}

REPP worked extensively with the Geothermal Energy Association (GEA), the Solar Energy Industries Association (SEIA), and the American Association of Wind Energy (AWEA) to identify market ready technologies, approaches to development and implementation of the Jobs Calculator, and potential outreach opportunities. Recommendations from the Advisory Council led to the focus on the Wind, Solar, Geothermal, and Biomass technologies. Industry surveys from these various associations were a crucial component in the development of the Jobs Calculator. The Advisory Council recommended that REPP work to develop interest at the state level for the output of the project. This resulted in the development of several state-level reports including the States of Ohio, Pennsylvania, Wisconsin, and Michigan.

The Advisory Council's influence in the solar and renewable community led to the use of the Job Calculator and Locator for a variety of products - such as the U.S. Photovoltaic Industry Roadmap, cited in NREL and ORNL reports, etc. 


\section{Task 2: Develop Expanded Jobs Calculator}

The upgraded and expanded Jobs Calculator allows more precise calculations of the economic development benefits related to renewable energy development. The upgraded Jobs Calculator has the following benefits:

- Expands the survey to include the other renewable technologies, such as biomass, solar thermal, geothermal, landfill gas, and other renewable technologies;

- Calculates more precisely the economic development benefits related to renewable energy development;

- Completes and regularly updates the survey of the commercially active renewable energy firms to determine the kinds and number of jobs directly created as a result of commercial installations of renewable energy; and

- Implements a methodology to locate where the economic activity related to each type of renewable technology is likely to fall.

The Jobs Calculator produces three results that are useful to states trying to secure the greatest possible economic advantage from accelerated renewable energy development:

1. Identification of potential skill gaps;

2. Variation of jobs created per MW of installed capacity by the various eligible technologies; and

3. Variation of jobs by manufacturing, installation, and operation and maintenance.

\section{How the Jobs Calculator works}

The Jobs Calculator is based on a survey of current industry practices to assess the number and type of jobs that will result from the enactment of a Renewable Portfolio Standard or other legislation and programs to accelerate renewable energy development.

The program-specific surveys examine manufacturing, installation, and operating and maintenance $(\mathrm{O} \& \mathrm{M})$ practices by occupational category as well as by project activities for each renewable energy technology analyzed.

One the required installed capacity to meet an RPS, other legislation or program is specified, the calculator will determine the number and types of jobs in each of those major areas of activity by year per installed MW of capacity. The calculator estimates the total direct labor required to manufacture, install, operate and service the specific renewable energy technology and the total direct labor to collect, transport, and process fuel where applicable. The following example is 


\section{from the Jobs Calculator based on the implementation of the Nevada Renewable Portfolio Standard.}

N evada RPS Implementation

\begin{tabular}{|c|c|c|c|c|c|c|c|c|c|c|}
\hline Renewable Energy Labor & Calculator-Nevada & RPS & Example, & $2003-2$ & 2013 & & & & & \\
\hline \multicolumn{11}{|l|}{ User Inputs } \\
\hline Generation & $2003 \quad 2004$ & 2005 & 2006 & 2007 & 2008 & 2009 & 2010 & 2011 & 2012 & 2013 \\
\hline $\begin{array}{l}\text { Total Retail Sales ( } 1000 \mathrm{KWh}) \\
\text { RPS Requirement }(\% \text { of Total Retail Sales) } \\
\text { RPS Gene ration Require ment ( } 1000 \mathrm{KWh} \text { per year) }\end{array}$ & $\begin{array}{cc}27,864,303 & 28,282,268 \\
5 \% & 5 \% \\
1,393,215 & 1,414,113\end{array}$ & $\begin{array}{c}28,706,502 \\
7 \% \\
2,009,455\end{array}$ & $\begin{array}{c}29,137,099 \\
7 \% \\
2,039,597\end{array}$ & $\begin{array}{c}29,574,156 \\
9 \% \\
2,661,674\end{array}$ & $\begin{array}{c}30,017,768 \\
9 \% \\
2,701,599\end{array}$ & $\begin{array}{c}30,468,035 \\
11 \% \\
3,351,484\end{array}$ & $\begin{array}{c}30,925,055 \\
11 \% \\
3,401,756\end{array}$ & $\begin{array}{c}31,388,931 \\
13 \% \\
4,080,561\end{array}$ & $\begin{array}{c}31,859,765 \\
13 \% \\
4,141,769\end{array}$ & $\begin{array}{c}32,337,661 \\
15 \% \\
4,850,649\end{array}$ \\
\hline Renewable Generation Mix (\%) & 2004 & 2005 & 2006 & 2007 & 2008 & 2009 & 2010 & 2011 & 2012 & 2013 \\
\hline Wind & $50 \%$ & $50 \%$ & $50 \%$ & $50 \%$ & $50 \%$ & $50 \%$ & $50 \%$ & $50 \%$ & $50 \%$ & $50 \%$ \\
\hline PV & $30 \%$ & $30 \%$ & $30 \%$ & $30 \%$ & $30 \%$ & $30 \%$ & $30 \%$ & $30 \%$ & $30 \%$ & $30 \%$ \\
\hline Biomass Cofiring & $10 \%$ & $10 \%$ & $10 \%$ & $10 \%$ & $10 \%$ & $10 \%$ & $10 \%$ & $10 \%$ & $10 \%$ & $10 \%$ \\
\hline Geothermal & $10 \%$ & $10 \%$ & $10 \%$ & $10 \%$ & $10 \%$ & $10 \%$ & $10 \%$ & $10 \%$ & $10 \%$ & $10 \%$ \\
\hline Renewable Generation Capacity Factors & \multicolumn{10}{|l|}{ Capacity Factor } \\
\hline Wind & 0.35 & & & & & & & & & \\
\hline & 0.25 & & & & & & & & & \\
\hline Biomass Cofiring & 1.00 & & & & & & & & & \\
\hline Geothermal & 0.90 & & & & & & & & & \\
\hline \multicolumn{11}{|l|}{ Additional parameters } \\
\hline Percent co-fire & $5 \%$ & & & & & & & & & \\
\hline Hours per FTE & 2000 & & & & & & & & & \\
\hline Annual growth rate of retail sales & $1.5 \%$ & & & & & & & & & \\
\hline
\end{tabular}

\section{Labor Totals, 2003-2013}

\begin{tabular}{|l|c|c|c|c|}
\hline L ab or Totals, 2003-2013 & $\begin{array}{c}\text { Manufac turing Jobs } \\
\text { (FTE) }\end{array}$ & $\begin{array}{c}\text { Installation Jobs } \\
\text { (FTE) }\end{array}$ & $\begin{array}{c}\text { O\&M Jobs } \\
\text { (FTE) }\end{array}$ & $\begin{array}{c}\text { Total jobs by } \\
\text { Technology }\end{array}$ \\
\hline Technology & 2,476 & 530 & 751 & 3,757 \\
Wind & 16,662 & 4,817 & 1,661 & 23,140 \\
PV & n/a & nia & 89 & 89 \\
Biomass Co-firing* & n/a & nia & 243 & 243 \\
\hline Geothermal** & $\mathbf{1 9 , 1 3 8}$ & $\mathbf{5 , 3 4 7}$ & $\mathbf{2 , 7 4 4}$ & $\mathbf{2 7 , 2 2 9}$ \\
\hline Totalby Job type &
\end{tabular}

\begin{tabular}{|l|c|c|}
\hline \multicolumn{3}{|c|}{ Capacity Totals, 2003-2013 } \\
\hline Technology & Cumulative Installed & Curnulative Capacity \\
\hline Wind & 791 & $(\%)$ \\
\hline PV & 664 & $50 \%$ \\
Biomass Co-firing* & 55 & $42 \%$ \\
Geothe rmal** & 62 & $4 \%$ \\
Total & $\mathbf{1 , 5 7 2}$ & $4 \%$ \\
\hline
\end{tabular}

*Assumes silvicultural wood only, wo otherbiomass fiels. Biomass co-firing does not inchude O\&M of the coal-fired power plant, only the growth, harrestine, tars port, and preparation of biomass fiels

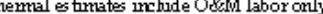

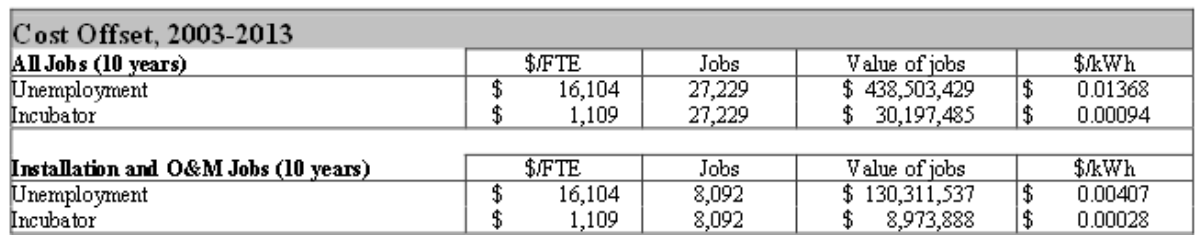




\section{Task 3: Develop Jobs Locator}

The development of the Jobs Locator involved a review of U.S. Census of Manufacturing data using six-digit NAICS (North American Industrial Classification System) codes to identify firms, numbers of employees, and facility locations.

In addition to providing this information either in a consolidated format (nationally, program-specific) as well as detailed at the state level, adding the energy manufacturing and sub-component manufacturing locations to the database provides other benefits. REPP devised a methodology to gauge the dispersion of economic impacts that can be expected from a typical project and uses that to determine where, for example, the ripples of a national program to push wind development might be felt. It should be stressed that this methodology identifies areas where industries with the capability to provide necessary components are located. This methodology required the development of customized data from the Census of Manufacturing. The geographic dispersion of economic activity that can be expected to occur as a result of the expansion of installed wind or other renewable energy capacity is an important dimension of the economic impact, but one that is not at all understood at this time. Using the survey basis of the Jobs Calculator to also determine the geographic dispersion of the renewable energy industry adds an important component to supporting efforts to develop renewable energy.

\section{How the Jobs Locator Works (Wind Energy example)}

Step 1 - Identify components of wind turbine

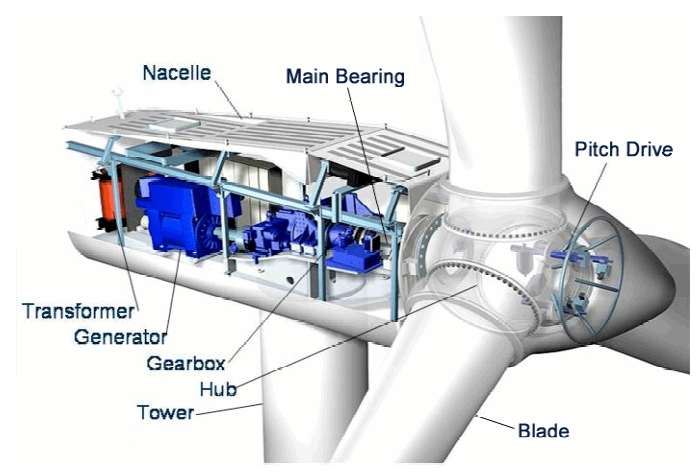

Step 2 - link component to 6-digit NAICS

Component

Main
Bearing $\longrightarrow$

Results: 16,163 establishments identified related to wind energy
NAICS Industry

3329913032 - Tapered roller bearings Bearings

332991 - Ball and Roller 
Step 3 - Distribute $\$$ and Jobs by Industry

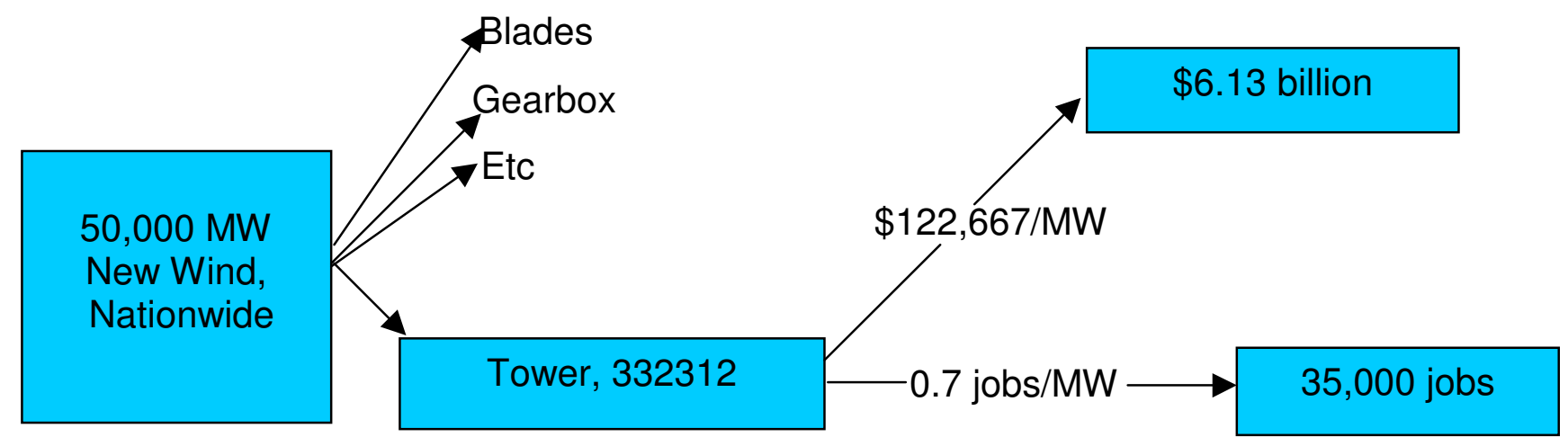

Note: A "job" equals 2000 hrs. Of labor

Step 4 - Allocate Geographically by Census Data (State of Kentucky example)

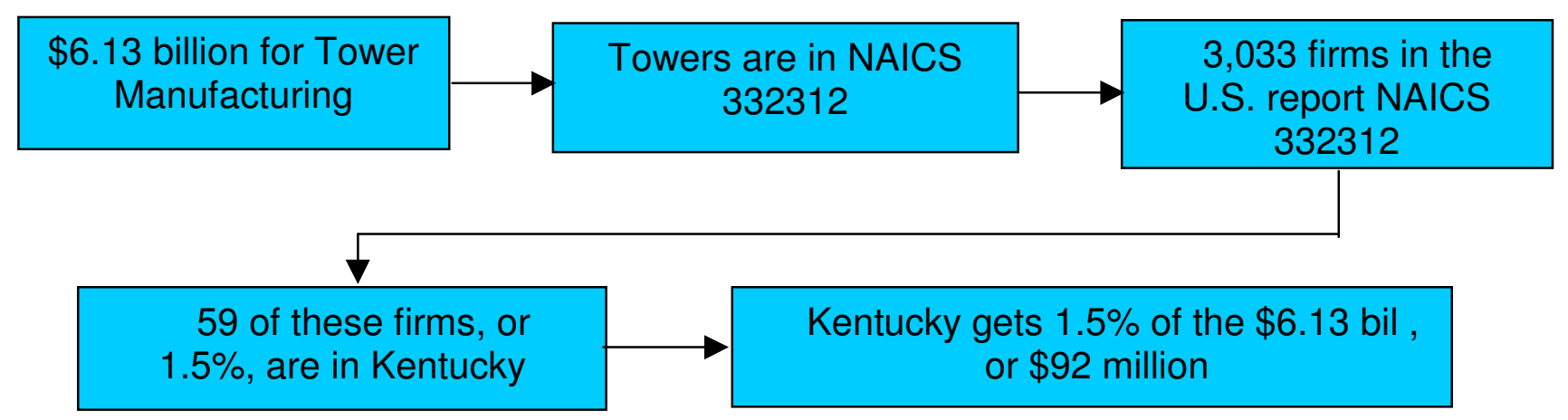

This method is repeated for all components and summed to get the total for each state. 
Using this methodology REPP developed the following summary of national development, resulting investment and jobs for the combined renewable technologies of wind, solar, geothermal, and biomass generators. For the combined renewable technologies, we assumed that $185,000 \mathrm{MW}$ of wind would be developed, 23,150 MW of photovoltaic, 21,760 MW of biomass, and 15,190 MW of geothermal.

Summary of National Development, Resulting Investment and Jobs

\begin{tabular}{lcccc}
\hline Technology & \# of MW & \# of Firms & Investment & $\begin{array}{c}\text { New FTE } \\
\text { Jobs }\end{array}$ \\
\hline Wind & 124,900 & 16,480 & $\$ 62,338$ & 398,470 \\
Solar & 23,150 & 10,272 & $\$ 69,624$ & 298,194 \\
Geothermal & 15,190 & 3,926 & $\$ 15,330$ & 72,324 \\
Biomass & 21,760 & 12,020 & $\$ 13,248$ & 81,615 \\
TOTAL & $\mathbf{1 8 5 , 0 0 0}$ & $\mathbf{4 2 , 6 9 8}$ & $\mathbf{\$ 1 6 0 , 5 4 1}$ & $\mathbf{8 5 0 , 6 0 3}$ \\
\hline
\end{tabular}

Nearly 43,000 firms throughout the United States operate in industries related to the manufacturing of components that go into renewable energy systems. If the $185,000 \mathrm{MW}$ of renewable energy assumed in this model were to be developed, these companies have the potential to fill the demand for new components that would be generated. This national development would represent nearly $\$ 160.5$ billion dollars of manufacturing investment, and would result in more than 850,600 new jobs 


\section{Program-specific Reports}

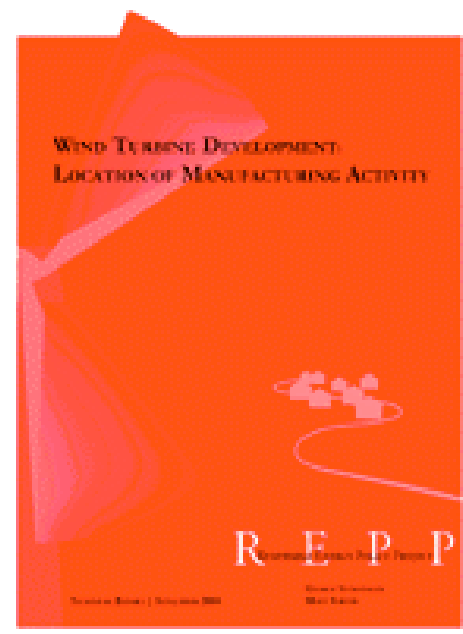

Over 16,000 firms in all 50 states have the technical potential to enter the growing wind turbine manufacturing sector, according to research recently completed by REPP. The results indicate that a national investment in wind has the clear potential to benefit regions of the U.S. other than those with a wind resource. The 20 states that would potentially benefit the most, receiving $80 \%$ of the job creation, are the same states that account for $76 \%$ of the manufacturing jobs lost in the U.S. over the last $31 / 2$ years.

This report shows that a substantial portion of the benefits from wind energy will result from manufacturing the equipment and will flow to those states and localities that either have or can develop the firms to supply the subcomponents. The report takes a modern wind turbine and reduces it to its 20 separate component parts. The report first identifies 90 companies in 25 states already active in manufacturing these components. As a second step, the report identifies the number of companies with the technical potential to enter the wind turbine market. Based on this analysis, the report shows that the manufacturing activity related to the development of wind energy is substantial and widely dispersed. There are 16,163 firms currently related to the manufacturing of wind components. These firms are spread over every one of the 50 states, however, they are concentrated in the most populous states, and the states that have suffered the most from loss of manufacturing jobs.

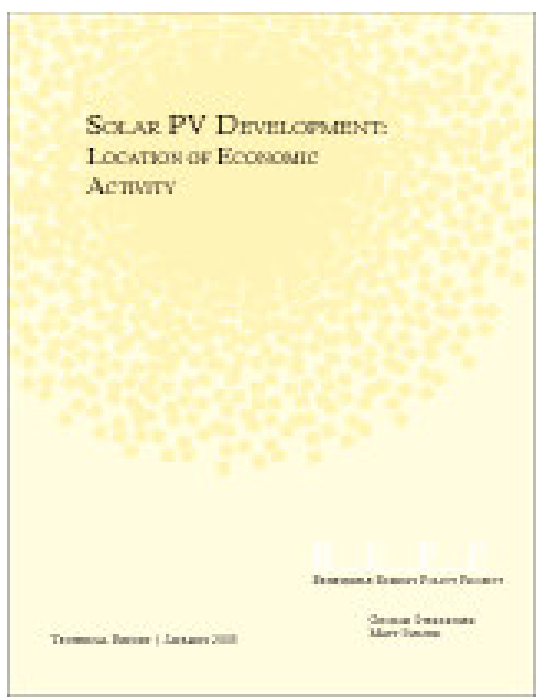

Development of solar PV will lead to jobs and investment in areas of the country that manufacture the parts that make up a PV system, in addition to locations that install the systems. 
The Solar PV Development report shows that manufacturing and installation of PV systems benefits locations throughout the U.S., and particularly in places that need it the most. All but 5 states would receive at least $\$ 100$ million in investment, based on the industry goals set forth in the PV Roadmap. Furthermore, the 20 states that would benefit the most from PV are states that have lost the most manufacturing jobs in the last few years.

\section{State Reports}

It is clear from earlier analyses undertaken by the Renewable Energy Policy Project that many of the states and regions that have suffered the greatest loss of manufacturing jobs have a significant concentration of manufacturing potential to supply those components. This potential is little understood even by those closest to it and who stand to benefit the most from it. The REPP State Reports intend to provide an explanation of how this manufacturing potential is calculated and offer detailed analysis showing for a state, region, and county the potential for each of the 43 industrial codes that comprise the major component parts for the major renewable energy technologies. It is hoped that the Reports will spur interest at the local level to actually identify the specific firms that could benefit from a national program and begin the discussion as to how best to tie reinvigorated domestic manufacturing activity into a national program to develop renewable energy.

Every REPP State Report provides detailed information about the potential job creation and economic stimulus of national renewable energy development efforts down to the county level. To make the results of these reports more readily available to the general public, REPP links the State Reports data to GOOGLE Maps. This allows REPP to offer a web based output that will allow anyone to "see", where the firms are located that have the potential to become a part of the 21 st Century Renewable Manufacturing Industry.

To date, REPP has completed reports for the states of Ohio, Wisconsin, Michigan, Pennsylvania, and California.

Using the Pennsylvania report as an example, REPP analysis shows that approximately 4,636 MW of wind, biomass, and solar will be developed in the state as a result of this initiative. Every $1000 \mathrm{MW}$ of wind developed could provide as many as 3,000 manufacturing jobs, 600 installation jobs, and 300 jobs in on-going operations and maintenance. The analysis shows that up to 30,700 full-time equivalent direct jobs would be created over the ten-year lifetime of the RPS. Of these, approximately 20,700 are in manufacturing; 5, 000 are in construction and installation; and 5,000 are in operations and maintenance. The survey examined manufacturing, installation, and operating and maintenance practices by occupational category as well as by project activities for each renewable energy technology analyzed. 


\section{Task 4: Outreach}

As a part of its outreach efforts, REPP staff has made presentations on the Jobs Calculator and Jobs Locator for the following organizations/forums.

\begin{tabular}{|l|l|}
\hline Solar Energy Industries Association & American Wind Energy Association \\
\hline Geothermal Energy Association & Ohio Wind Energy Group \\
\hline North Carolina Wind Working Group & U.S. International Trade Commission \\
\hline Nevada Economic Development Comm & EIA 2005 Annual Energy Outlook Conf \\
\hline $\begin{array}{l}\text { New England Sustainable Energy } \\
\text { Association Conference }\end{array}$ & AWEA Annual Conference \\
\hline SolarGenerations Conference & \\
\hline
\end{tabular}

Separate presentations have been made to various state level environmental/energy/economic development groups in the states of:

- Pennsylvania

- Ohio

- Michigan

- Wisconsin

- California

- Kentucky

- Nevada

In addition, copies of the Solar PV Development and Wind Energy Economic activity reports were provided to all state energy offices and national non-profit organizations interested in renewable technology development. Copies of all reports are available on the REPP website: www.repp.org

For Tasks 5, 6, and 7 - REPP worked with the Nevada AFL-CIO to identify and capture opportunities for skilled labor that resulted from new renewable energy projects resulting from the Renewable Portfolio Standard in general and AB431 in particular. The REPP Jobs Calculator identifies three major opportunities/challenges facing a state developing new renewable energy. A skills gap can result if training is inadequate. Technology selection can increase total jobs. Finally, incentives provided to renewable developers can influence manufacturing to locate in the state. REPP and the Nevada AFL-CIO collaborated in addressing these challenges in Nevada.

\section{Task 5: Form Nevada Advisory Committee to Review Opportunities and Determine Appropriate Response to Renewable Opportunities}

The Nevada Advisory Committee was formed immediately after grant award.

The Committee is made up of Danny Thompson, Secretary of the Nevada AFL- 
CIO; David Jones, Business Manager of IBEW Local 357; Madison Burnett, Training Director of Electrical JATC for Southern Nevada; and George Sterzinger, Executive Director, REPP. The Advisory Committee met at least quarterly during the duration of the project.

The Advisory Committee had several specific mandates:

- Evaluate Training Program options to address skills gap

The Advisory Committee chartered a Training Advisory Committee that through a series of meeting and conference calls developed a plan and timeline for designing and implementing a training program for installers of photovoltaic energy systems. Members of the Training Advisory Committee traveled to the International Brotherhood of Electrical Workers (IBEW)/National Electrical Contractors Association (NECA) training facility and researched installer certification programs to assist in identifying an appropriate training curriculum and certification process for PV installer training.

Three prospective instructors were sent to train-the-trainers sessions in Alcoa, Tennessee for the purpose of qualifying them to deliver the planned photovoltaic installation training. Appropriate curriculum and textbooks were purchased for two photovoltaic installer training courses - Photovoltaic Levels I and II.

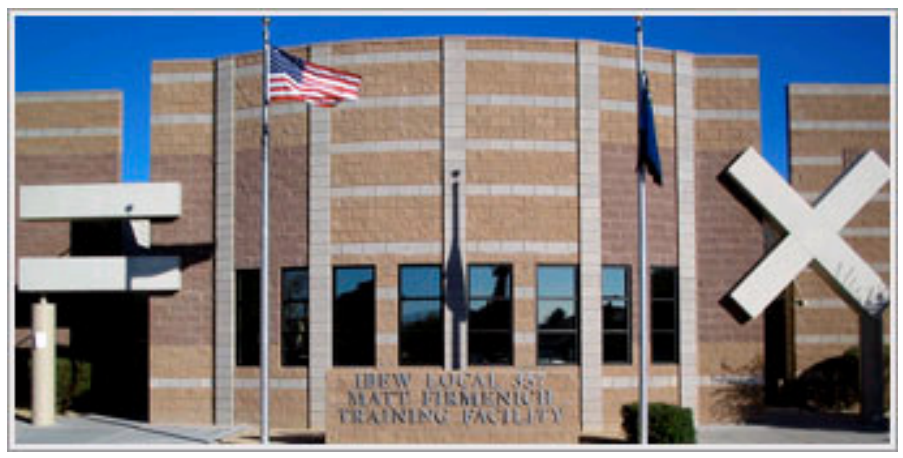

IBEW of Southern Nevada Local \#357 Training Facility Las Vegas, NV

- Review opportunities for obtaining PV hardware for training program development

Another important component of the training program is the hands-on demonstration part of the program that allows trainees to gain experience in a real-world environment by using a working model of a photovoltaic system installed on the roof of the training building. A shaded parking structure utilizing PV panels was also constructed. The unique feature of the parking structure is that it allows disassembly and re-assembly the classes of trainees. In addition to a training venue, the photovoltaic demonstration system provides increased public awareness and interest in the use of the technology. The IBEW 
negotiated a partnership with the Nevada Power Company for the installation of two photovoltaic panels in support of the training and demonstration program with funds available under $A B 431$.

A request for bids was sent out by the Southern Nevada Electrical JATC to five major equipment providers requesting proposals for a 20 kilowatt PV system. Bids were received from four firms. Sharp Manufacturing was selected to provide the appropriate equipment for installation of the parking structure and solar panels to be used to train apprentices in installation of PV systems. The selection was based on Sharp's technical experience and reputation as a domestic manufacturer of PV systems as well as lowest cost proposal.

In the Fall of 2006, the PV demonstration project was completed. To date over 100 people have successfully completed the initial phase of the PV installer training program, and the pilot program for PV panels continues to be oversubscribed. Trainees who complete the program will receive a national certification in addition to the NJATC and Nevada State certifications.

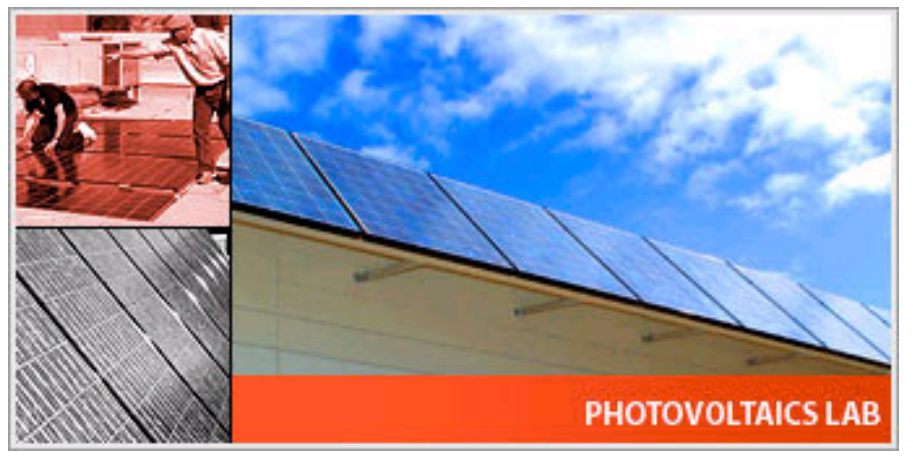

IBEW of Southern

Nevada Local \#357

Training Facility

Las Vegas, NV

- Technology Selection: Review Commission implementation plan for RPS. In particular, review the process for valuing the Renewable Energy Credits allowed for PV installations and the appropriate time-of-use rate for net metering of these projects

Members of the Advisory Committee and Danny Thompson as a member of the Governor's Task Force worked with the PUC and the Nevada utilities to negotiate a value for the REC credits in order to implement the AB431 pilot program. Time of Use rates continue to pose a hurdle for PV acceptance due to the extremely short peak period. The Advisory Committee also monitored the economic development benefits of a large Concentrating Solar Power project owned by the Spanish firm, Acciona S.A. This project has a contract for $63 \mathrm{MW}$ of power and promised to provide 300 local construction jobs but so far has failed to deliver these jobs. 
- Manufacturing Components: Review opportunities for other renewable technologies to supply economic diversity and local jobs

Members of the Advisory Committee met with representatives of the Nevada Office of Economic Development in late 2004 to begin initial discussions on the potential of attracting photovoltaic manufacturers to the state. A letter of inquiry was sent to a list of potential manufacturers to develop a list of contacts and generate interest in potential relocation. REPP held discussions with investment bankers active in the New Market Tax Credit field to determine if a Nevada manufacturing project might qualify for this type of investment.

In early 2005, REPP and the Nevada State AFL-CIO organized a fact-finding trip to meet with representatives of NanoSolar Technologies in Palo Alto, CA to explore potential for development of new technology manufacturing sites in Southern Nevada. An analysis of economic incentives and appropriate building stock was conducted for the potential of locating a rolling mill manufacturing center in Southern Nevada.

\section{Task 6: Participate in the Governor's Task Force on Renewable Energy}

REPP provided technical assistance to the Governor's Task Force on Renewable Energy including discussions and meetings on:

- Potential legislative and regulatory opportunities to further develop renewable energy projects

- Potential to revise existing Renewable Energy Credits, where appropriate

Project participants and consultants provided technical assistance on the development of training requirements for photovoltaic installers to members of the Nevada State House and Senate. A bill outlining the requirements for training, testing, and certification of photovoltaic installers was passed by the Nevada State Legislature. Project participants also provided continued technical assistance to the Nevada Department of Industrial Relations in the development of the final structure and regulations of the training and certification program.

In addition REPP provided technical expertise in the preparation of the Task Force Annual Report and to plan for public outreach activities to increase interest in photovoltaic systems.

\section{Task 7: Progress Conference}

Provide a Conference Forum for highlighting progress made in training installers, showcase PV equipment used in the training and installation business, and 
publicize exceptional efforts among homebuilders, businesses, schools, and public buildings installing PV.

The Progress Conference was held on July 17, 2006. The Conference announced the completion of the PV parking structure. It also served as an opportunity to review the overall progress of the IBEW training program. To date over 100 people have been through the initial phase of the training program. The pilot training program for PV panels continues to be oversubscribed. The Conference brought together decision-makers and statewide political leaders and candidates to discuss issues related to renewable energy training, manufacturing, consumer, government, and environmental concerns. The Conference announced the formation of the Nevada Energy Independence Partners to continue the work begun under this program. 


\section{Conclusion}

The economic stimulus that flows from renewable energy development is one means of convincing a greater diversity of audiences of the benefits of renewable energy. As a result, REPP believes this project will contribute to the understanding, interest in, and potential for increased public support of renewable energy. A national program to develop renewable energy will provide significant benefits to states and regions well beyond where projects are developed. A national program will greatly stimulate demand for manufactured components and will provide training and job opportunities in many areas of the nation. 